\title{
A knowledge survey of obstetrics and gynecology staff on the prevention of mother-to-child transmission of hepatitis B virus
}

\author{
Yali Hu ${ }^{1,2}$, Xinwei Dai ${ }^{1}$, Yi-Hua Zhou ${ }^{3}$, Huixia Yang ${ }^{4}$ \\ ${ }^{1}$ Department of Obstetrics and Gynecology, Nanjing Drum Tower Hospital, Nanjing Medical University, Jiangsu, \\ China \\ ${ }^{2}$ Department of Obstetrics and Gynecology, Nanjing Drum Tower Hospital, Nanjing University Medical School, \\ Jiangsu, China \\ ${ }^{3}$ Departments of Experimental Medicine and Infectious Diseases, Nanjing Drum Tower Hospital, Nanjing University \\ Medical School, Jiangsu, China \\ ${ }^{4}$ Department of Obstetrics and Gynecology, Peking University First Hospital, Peking University, Beijing, China
}

\begin{abstract}
Introduction: This survey was designed to investigate the knowledge awareness of obstetrics and gynaecology staff (Obs/Gyn staff) on the prevention of mother-to-child transmission (PMTCT) of hepatitis B virus (HBV).

Methodology: Obs/Gyn staff from 21 of the 31 Chinese mainland provinces, who attended medical meetings or training classes from July to October 2011, were invited to complete a questionnaire regarding PMTCT of HBV. The questionnaire included the clinical implications of HBV serologic markers and PMTCT preventive measures for both pregnant women and infants.

Results: A total of 828 questionnaires were distributed, 617 (74.5\%) Obs/Gyn staff participated in the survey, and 559 (90.6\%) questionnaires met the inclusion criteria. Overall, $90 \%$ of participants correctly determined the positive hepatitis B surface antigen (HBsAg) as infectious, but up to $27.5 \%$ mistakenly considered the presence of anti-HBe and/or anti-HBc with negative $\mathrm{HBsAg}$ as infectious. In total, 96.3\% respondents knew that pregnant women should be screened for HBV infection, and 95.3\% realized that infants of HBsAg-positive mothers should be injected with hepatitis B immunoglobulin and vaccine. On the other hand, with the available immunoprophylaxis, $13.8 \%$ participants mistakenly believed caesarean section may prevent HBV mother-to-child transmission, and only $13 \%$ correctly answered that newborns of HBsAg positive mothers may be breastfed.

Conclusion: Obs/Gyn staff in China have mastered the strategies of HBV PMTCT, but there is obvious insufficiency in details of the application. Intensified efforts to train the Obs/Gyn staff are required to improve the current suboptimal medical service in HBV-exposed infants and to control mother-to-infant transmission of HBV.
\end{abstract}

Key words: hepatitis B virus; mother-to-child transmission; immunoprophylaxis; knowledge awareness

J Infect Dev Ctries 2013; 7(5):391-397. doi:10.3855/jidc.2915

(Received 03 August 2012 - Accepted 18 September 2012)

Copyright (C) 2013 Hu et al. This is an open-access article distributed under the Creative Commons Attribution License, which permits unrestricted use, distribution, and reproduction in any medium, provided the original work is properly cited.

\section{Introduction}

Chronic hepatitis B virus (HBV) infection is a severe global health threat causing chronic hepatitis, cirrhosis, and hepatocellular carcinoma (HCC) [1]. It is estimated that 350 to 400 million people are chronically infected [2]. In China, the overall positive rate of hepatitis B surface antigen ( $\mathrm{HBsAg}$ ) is 7.18\% [3], and annually approximately 300,000 individuals die from HBV-related diseases including HCC $(40 \%$ to $50 \%$ of that of the entire world) [4]. Mother-to-child transmission of $\mathrm{HBV}$ leads to $80 \%$ to $90 \%$ chronic carriers [5]. Thus prevention of mother-to-child transmission (PMTCT) of HBV is of great importance.

The standard immunoprophylaxis against HBV is to give three doses of hepatitis $B$ vaccine to all newborns as follows: one at birth, and then again at one month and six months after birth. In addition, infants born to HBsAg carrier mothers should receive hepatitis B immunoglobulin (HBIG) within 12 hours after birth [6]. The strategy is highly effective in the prevention of mother-to-infant transmission of HBV, with $99.71 \%$ to $100 \%$ and $85 \%$ to $95 \%$ protective rates in children of $\mathrm{HBeAg}$-negative and $\mathrm{HBeAg}$-positive carrier mothers respectively [7-12]. However, the strategy is not very well implemented in developing countries, including China [13,14]. For instance, many high-risk infants born to $\mathrm{HBsAg}$ positive mothers failed to receive $\mathrm{HBIG}$ and the timely first dose vaccine, in both urban and rural areas $[15,16]$, and some unnecessary tests, such as testing for breast milk 
HBV DNA [17], and non-evidence-based interventions, such as Caesarean section for PMTCT [18], are still in practice. Obstetrics and gynecology medical staff (Obs/Gyn staff) play critical roles in PMTCT of HBV since they administer HBIG and/or first dose hepatitis B vaccine to newborn infants. We conducted this survey to determine whether these inappropriate measures are due to the lack of knowledge in Obs/Gyn staff, so that education programs can be developed to reinforce the ability of Obs/Gyn staff to conduct PMTCT.

\section{Methodology}

Study subjects and questionnaires

This survey targeted the Obs/Gyn medical personnel from hospitals in 21 out of the 31 provinces in mainland China, who attended medical meetings or training classes from July to October 2011, excluding non-Obs/Gyn staff, undergraduate medical students, and those who had practiced in Obs/Gyn for fewer than two months. A questionnaire regarding PMTCT of $\mathrm{HBV}$, containing the clinical significance of $\mathrm{HBV}$ serologic markers and relevant PMTCT measures, including those for both pregnant women and infants, was distributed among the subjects. The questionnaire was anonymous. The personal data and employers' information were kept confidential. We collected the questionnaires on the spot when they were completed. The questionnaire was in Chinese, but an English version can be provided upon request.

\section{Data analysis}

The data were statistically analyzed using SPSS Package version 13.0 (IBM SPSS Inc., Chicago, IL, USA). We used analysis of variance to compare the mean numbers, and used chi square test as well as Fisher exact probability test to compare proportions. P $<0.05$ was considered to be statistically significant.

\section{Results}

Demographics

Of the total $828 \mathrm{Obs} / \mathrm{Gyn}$ staff who were asked to complete the questionnaires, $617(74.5 \%)$ participated in the survey. In the end, $559(90.6 \%)$ questionnaires were included in this study, since 35 questionnaires were unfinished and the 23 others who did not meet the inclusion criteria were excluded. Of the 559 respondents, 194 (34.7\%), 193 (34.5\%), and 172 (30.8\%) had worked for over 20,11 to 20 , and 1 to 10 years, respectively; 240 (42.9\%), 124 (22.2\%), and $111(19.9 \%)$ were chief, attending, and resident doctors, respectively, and $84(15.0 \%)$ were nurses.
Overall, 389 (69.6\%) respondents were employed by general hospitals and 279 (49.9\%) were employed by Level 3 hospitals, which is the top level in China.

\section{Basic knowledge/awareness of hepatitis $B$}

The knowledge regarding HBV PMTCT of the participants was obtained from medical school (71.6\%), academic lectures $(69.9 \%)$, self-consulting relevant data $(64.0 \%)$, and colleagues $(32.0 \%)$, respectively. The proportion sum exceeding $100 \%$ is due to the multiple selections. No statistically significant differences were found among the accuracy rates of the basic knowledge of hepatitis $\mathrm{B}$ of respondents with the above knowledge sources (data not shown).

We designed a 12-question test about HBV serologic markers determination, consisting of 12 combination of the five $\mathrm{HBV}$ serologic markers (HBsAg, anti-HBs, HBeAg, anti-HBe, and anti-HBc), with positive or negative status for each. Respondents were asked to clarify the clinical significance of each combination. Overall, $90 \%$ of the participants correctly determined the positive HBsAg as infectious, but up to $27.5 \%$ mistakenly considered the presence of anti-HBe and/or anti-HBc with negative HBsAg as infectious; $81.4 \%$ of the respondents correctly determined the positive anti-HBs as immune to HBV, but $35.6 \%$ erroneously considered having the presence of anti-HBe and/or anti-HBc in the absence of antiHBs as immune to HBV.

The correct rates with regard to HBV serologic markers determination were related to respondents' education levels, titles, work seniorities, as well as levels and properties of the hospitals where they were working. Generally, respondents with higher education backgrounds had higher accuracy rates, and those working longer, with higher titles, or working in higher level hospitals were inexplicably less correct ( $\mathrm{P}$ $<0.05)$.

\section{PMTCT measures for pregnant women}

As shown in Table 1, most $(96.3 \%)$ of the participants knew that pregnant women should be routinely screened for HBV infection, while $3.3 \%$ still believed it should be determined based on specific situations (e.g., with an HBsAg-positive family history, or with abnormal liver function). With respect to whether HBsAg-positive pregnant women can breastfeed, only $13.0 \%$ respondents correctly answered that "newborns could be breastfed after administration of HBIG and full-dose vaccine"; while 
Table 1. Correct rates on preventive measures towards HBsAg carrier pregnant women ${ }^{*}$

\begin{tabular}{|c|c|c|c|c|c|c|c|c|c|}
\hline \multirow{2}{*}{$\begin{array}{c}\text { Measures } \\
\text { (correct answer) }\end{array}$} & \multirow{2}{*}{ Correct/Total (\%) } & \multicolumn{4}{|c|}{ Hospital level $^{\dagger}$} & \multicolumn{4}{|c|}{ Hospital Property } \\
\hline & & 1 & 2 & 3 & $\chi^{2 / P}$ & General & Maternity & FPC & $\chi^{2} / P$ \\
\hline $\begin{array}{l}\text { Need for HBV } \\
\text { screening during } \\
\text { pregnancy? } \\
\text { (yes) }\end{array}$ & $519 / 539(96.3)$ & $\begin{array}{l}68 / 72 \\
(94.4)\end{array}$ & $\begin{array}{l}201 / 203 \\
(99.0)\end{array}$ & $\begin{array}{l}250 / 264 \\
(94.7)\end{array}$ & $6.780 / 0.034$ & $\begin{array}{c}363 / 375 \\
(96.8)\end{array}$ & $\begin{array}{c}124 / 132 \\
(93.9)\end{array}$ & $32 / 32(100)$ & $2.807 / 0.225$ \\
\hline $\begin{array}{l}\text { Need caesarean } \\
\text { section for } \\
\text { PMTCT? (no) }\end{array}$ & $462 / 536(86.2)$ & $\begin{array}{l}64 / 72 \\
(88.9)\end{array}$ & $\begin{array}{c}177 / 202 \\
(87.6)\end{array}$ & $\begin{array}{c}221 / 262 \\
(84.4)\end{array}$ & $1.534 / 0.464$ & $\begin{array}{c}321 / 373 \\
(86.1)\end{array}$ & $\begin{array}{c}110 / 131 \\
(84.0)\end{array}$ & $\begin{array}{l}31 / 32 \\
(96.9)\end{array}$ & $3.618 / 0.164$ \\
\hline $\begin{array}{l}\text { Need HBV DNA } \\
\text { test for breast } \\
\text { milk? (no) }\end{array}$ & $103 / 534(19.3)$ & $\begin{array}{l}14 / 72 \\
(19.4)\end{array}$ & $46 / 202(22.8)$ & $43 / 260(16.5)$ & $2.839 / 0.242$ & 72/371 (19.4) & $24 / 131(18.3)$ & $7 / 32(21.9)$ & $0.220 / 0.896$ \\
\hline $\begin{array}{l}\text { Can HBV } \\
\text { carrier mothers }\end{array}$ & 69/532 (13.0) & $9 / 72(12.5)$ & 23/201 (11.4) & $37 / 259(14.3)$ & $0.827 / 0.661$ & $49 / 369(13.3)$ & $19 / 131(14.5)$ & $1 / 32(3.1)$ & $3.052 / 0.217$ \\
\hline
\end{tabular}

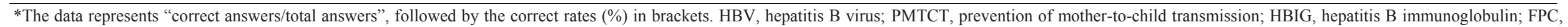
family planning centre. †Level 3 refers the highest level hospital in China. 
$69.0 \%$ respondents answered that "it depends on HBV serologic markers status or HBV DNA in breast milk". Similarly, $81.7 \%$ incorrectly considered that it is necessary to test HBV DNA in milk. In addition, $13.8 \%$ of the respondents believed that Caesarean section can reduce mother-to-child transmission risk of $\mathrm{HBV}$, although this is not the case.

With regard to the likelihood of antiviral therapy reducing mother-to-infant transmission, $11.7 \%$ of the participants considered it necessary to implement antiviral treatment with nucleoside drugs (e.g., lamivudine) for $\mathrm{HBsAg}$ carrier pregnant women, whereas $42.1 \%$ considered it not necessary and $21.6 \%$ considered it dependent upon HBV serologic markers; and $13 \%$ others considered that further study is needed. There was a significant difference among the correct rates of respondents from different types of hospitals $(\mathrm{P}=0.008)$.

\section{PMTCT measures for newborns}

Over $95 \%$ of the participants realized that infants of mothers with positive HBsAg should be injected with HBIG and vaccine (Table 2); nevertheless, only $61.6 \%$ and $80.4 \%$ knew the right injection method of HBIG and proper immunization program of the vaccine, respectively. In spite of that, just $84.5 \%$ of the respondents answered that HBIG was "almost always" injected into infants of HBsAg carrier mothers in practice. In addition, $61.8 \%$ of the respondents mistakenly believed that those infants should be tested for the presence of HBV markers in the cord blood.

In practice, when a pregnant woman's HBsAg status remained unknown at delivery, $71.9 \%$ respondents would have an emergency test, while others would treat it as negative $(19.3 \%)$ or positive $(6.6 \%)$. Over $51 \%$ of the respondents said they would "almost always" take the initiative to follow up the infants of HBsAg-positive mothers, and $27 \%$ would "sometimes" do that.

\section{Discussion}

This survey shows that the vast majority of the Obs/Gyn staff in China are aware of routine screening for HBV serologic markers in pregnant women, and know the immunoprophylaxis of combination HBIG and vaccine to the high-risk infants for PMTCT. However, the Obs/Gyn staff in China does not fully understand the significance of HBV serologic markers. Additionally, many Obs/Gyn staff are confused on the issues of whether HBsAg-positive pregnant women need detection of milk HBV DNA, whether they can breastfeed their infants, and whether cord blood needs measurement of $\mathrm{HBV}$ markers to determine if the infants are infected.

Antenatal screening for HBV serologic markers during pregnancy is of great significance in the prevention of HBV mother-to-infant transmission [19]. Given the possibility that some pregnant women may not tell the true histories of HBV infection because of their worries about the potential discrimination against HBV carriers, and that ad-hoc infection may occur during the pregnancy, Obs/Gyn physicians cannot exclude HBV infection in pregnant women only based on the history or pre-pregnancy testing results. On the other hand, if anti-HBs were once positive before pregnancy, there is little possibility of re-infection with HBV since immunity has been established. Hwang et al. [20] found financial barriers and the health provider's knowledge mainly influence HBV screening among Asian Americans. Considering Obs/Gyn physicians in our survey have high awareness of routine HBV screening for pregnant women, financial barriers may be the leading cause that affects the completeness of universal screening for pregnant women in developing countries.

Historically, some measures were implemented for PMTCT of HBV, such as performing Caesarean section [21] and avoiding breastfeeding [22]. However, many studies have confirmed that these two measures cannot reduce the rate of mother-to-child transmission after standard immunoprophylaxis [2327]. Although most respondents $(86.2 \%)$ considered it unnecessary to perform Caesarean section for PMTCT, the awareness rate still needs to be further improved. As for the breastfeeding issue, the majority of respondents believed it depends on HBV serologic markers of milk to determine whether HBsAg carrier mothers can breastfeed. The lack of this knowledge may result from delayed updates of relevant textbooks and reference books in Chinese.

To date, there have been no definite conclusions on the issue of whether HBV infected pregnant women during the third trimester should take the antiviral drugs for PMTCT [28-30]. Further research remains to be conducted to clarify this issue. However, $11.7 \%$ of the respondents in this survey thought antiviral therapy is necessary. Similarly, a survey conducted in the United States [31] also found physicians' attitudes on this issue to be undefined. In that survey, $51.8 \%$ physicians would initiate antiviral treatment during pregnancy. Absence of appropriate guidelines (60.4\%) and lack of evidence to support either safety (32.1\%) or efficacy $(7.5 \%)$ are responsible for the caution of 
Table 2. Preventive measures towards newborns of HBsAg carrier mothers*

\begin{tabular}{|c|c|c|c|c|c|c|c|c|c|c|}
\hline \multirow{2}{*}{\multicolumn{2}{|c|}{ Measures (correct answer) }} & \multirow{3}{*}{$\begin{array}{c}\begin{array}{c}\text { Correct/Total } \\
(\%)\end{array} \\
511 / 536(95.3)\end{array}$} & \multicolumn{4}{|c|}{ Hospital level $^{\dagger}$} & \multicolumn{4}{|c|}{ Hospital Property } \\
\hline & & & \multirow{2}{*}{$\begin{array}{c}1 \\
69 / 72 \\
(95.8)\end{array}$} & \multirow{2}{*}{$\begin{array}{c}2 \\
196 / 203 \\
(96.6)\end{array}$} & \multirow{2}{*}{$\begin{array}{c}3 \\
246 / 261 \\
(94.3)\end{array}$} & \multirow{2}{*}{$\frac{\chi^{2} / P}{1.403 / 0.496}$} & \multirow{2}{*}{$\begin{array}{c}\text { General } \\
359 / 373 \\
(96.2)\end{array}$} & \multirow{2}{*}{$\begin{array}{c}\text { Maternity } \\
122 / 131 \\
(93.1)\end{array}$} & \multirow{2}{*}{$\begin{array}{c}\text { FPC } \\
30 / 32 \\
(93.8)\end{array}$} & \multirow{2}{*}{$\frac{\chi^{2} / P}{2.311 / 0.315}$} \\
\hline $\begin{array}{l}\text { Need for HBIG injection } \\
\text { at birth? (yes) }\end{array}$ & Correct rates & & & & & & & & & \\
\hline \multirow{3}{*}{$\begin{array}{l}\text { Is HBIG administered to } \\
\text { newborns in your } \\
\text { hospital in practical } \\
\text { work? }\end{array}$} & $\begin{array}{l}\text { Almost } \\
\text { always }\end{array}$ & $453 / 536(84.5)$ & $\begin{array}{l}63 / 72 \\
(87.5)\end{array}$ & $\begin{array}{c}175 / 203 \\
(86.2)\end{array}$ & $\begin{array}{c}215 / 261 \\
(82.4)\end{array}$ & \multirow{3}{*}{$2.168 / 0.705$} & $\begin{array}{c}321 / 373 \\
(86.1)\end{array}$ & $\begin{array}{c}108 / 131 \\
(82.4)\end{array}$ & $\begin{array}{l}24 / 32 \\
(75.0)\end{array}$ & \multirow{3}{*}{$6.844 / 0.126$} \\
\hline & Sometimes & $42 / 536(7.8)$ & $\begin{array}{l}5 / 72 \\
(6.9)\end{array}$ & $\begin{array}{c}15 / 203 \\
(7.4)\end{array}$ & $\begin{array}{c}22 / 261 \\
(8.4)\end{array}$ & & $\begin{array}{c}24 / 373 \\
(6.4)\end{array}$ & $\begin{array}{c}15 / 131 \\
(11.5)\end{array}$ & $\begin{array}{l}3 / 32 \\
(9.4)\end{array}$ & \\
\hline & Others ${ }^{\S}$ & $41 / 536(7.6)$ & $\begin{array}{l}4 / 72 \\
(5.6)\end{array}$ & $\begin{array}{c}13 / 203 \\
(6.4)\end{array}$ & $\begin{array}{c}24 / 261 \\
(9.2)\end{array}$ & & $\begin{array}{c}28 / 373 \\
(7.5)\end{array}$ & $\begin{array}{c}8 / 131 \\
(6.1)\end{array}$ & $\begin{array}{c}5 / 32 \\
(15.6)\end{array}$ & \\
\hline $\begin{array}{l}\text { Need detection of HBV } \\
\text { markers in cord blood? } \\
\text { (no) }\end{array}$ & Correct rates & $203 / 531(38.2)$ & $\begin{array}{l}28 / 72 \\
(38.9)\end{array}$ & $\begin{array}{l}61 / 201 \\
(30.3)\end{array}$ & $\begin{array}{c}114 / 258 \\
(44.2)\end{array}$ & $9.177 / 0.010$ & $\begin{array}{c}132 / 368 \\
(35.9)\end{array}$ & $\begin{array}{l}58 / 131 \\
(44.3)\end{array}$ & $\begin{array}{l}13 / 32 \\
(40.6)\end{array}$ & $2.973 / 0.226$ \\
\hline \multirow{4}{*}{$\begin{array}{l}\text { How do you manage the } \\
\text { pregnant women with } \\
\text { unknown HBsAg status } \\
\text { at delivery? }\end{array}$} & $\begin{array}{l}\text { Determine as } \\
\text { negative }\end{array}$ & $103 / 534(19.3)$ & $\begin{array}{c}9 / 72 \\
(12.5)\end{array}$ & $\begin{array}{l}42 / 203 \\
(20.7)\end{array}$ & $\begin{array}{r}52 / 259 \\
(20.1)\end{array}$ & \multirow{4}{*}{$11.097 / 0.074$} & $\begin{array}{l}77 / 372 \\
(20.7)\end{array}$ & $\begin{array}{c}23 / 130 \\
(17.7)\end{array}$ & $\begin{array}{l}3 / 32 \\
(9.4)\end{array}$ & \multirow{4}{*}{$6.237 / 0.357$} \\
\hline & $\begin{array}{l}\text { Determine as } \\
\text { positive }\end{array}$ & $35 / 534(6.6)$ & $\begin{array}{l}2 / 72 \\
(2.8)\end{array}$ & $\begin{array}{c}13 / 203 \\
(6.4)\end{array}$ & $\begin{array}{c}20 / 259 \\
(7.7)\end{array}$ & & $\begin{array}{c}21 / 372 \\
(5.6)\end{array}$ & $\begin{array}{c}13 / 130 \\
(10.0)\end{array}$ & $\begin{array}{l}1 / 32 \\
(3.1)\end{array}$ & \\
\hline & $\begin{array}{l}\text { Emergency } \\
\text { test }\end{array}$ & $384 / 534(71.9)$ & $\begin{array}{l}56 / 72 \\
(77.8)\end{array}$ & $\begin{array}{c}146 / 203 \\
(71.9)\end{array}$ & $\begin{array}{c}182 / 259 \\
(70.3)\end{array}$ & & $\begin{array}{c}265 / 372 \\
(71.2)\end{array}$ & $\begin{array}{l}91 / 130 \\
(70.0)\end{array}$ & $\begin{array}{l}28 / 32 \\
(87.5)\end{array}$ & \\
\hline & $\begin{array}{l}\text { Nothing } \\
\text { special }\end{array}$ & $12 / 534(2.2)$ & $\begin{array}{l}5 / 72 \\
(6.9)\end{array}$ & $\begin{array}{l}2 / 203 \\
(1.0)\end{array}$ & $\begin{array}{l}5 / 259 \\
(1.9)\end{array}$ & & $\begin{array}{l}9 / 372 \\
(2.4)\end{array}$ & $\begin{array}{l}3 / 130 \\
(2.3)\end{array}$ & $\begin{array}{l}0 / 32 \\
(0.0)\end{array}$ & \\
\hline \multirow{3}{*}{$\begin{array}{l}\text { Do you follow up the } \\
\text { infants born to HBsAg } \\
\text { carrier mothers? }\end{array}$} & $\begin{array}{l}\text { Almost } \\
\text { always }\end{array}$ & $274 / 534(51.3)$ & $\begin{array}{l}45 / 72 \\
(62.5)\end{array}$ & $\begin{array}{c}89 / 202 \\
(44.1)\end{array}$ & $\begin{array}{c}140 / 260 \\
(53.8)\end{array}$ & \multirow{3}{*}{$11.455 / 0.022$} & $\begin{array}{c}183 / 371 \\
(49.3)\end{array}$ & $\begin{array}{c}67 / 131 \\
(51.1)\end{array}$ & $\begin{array}{l}24 / 32 \\
(75.0)\end{array}$ & \multirow{3}{*}{$9.450 / 0.051$} \\
\hline & Sometimes & $144 / 534(27.0)$ & $\begin{array}{l}19 / 72 \\
(26.4)\end{array}$ & $\begin{array}{c}64 / 202 \\
(31.7)\end{array}$ & $\begin{array}{c}61 / 260 \\
(23.5)\end{array}$ & & $\begin{array}{c}108 / 371 \\
(29.1)\end{array}$ & $\begin{array}{c}31 / 131 \\
(23.7)\end{array}$ & $\begin{array}{c}5 / 32 \\
(15.6)\end{array}$ & \\
\hline & Others $^{\S}$ & $116 / 534(21.7)$ & $\begin{array}{c}8 / 72 \\
(11.1)\end{array}$ & $\begin{array}{c}49 / 202 \\
(24.3)\end{array}$ & $\begin{array}{c}59 / 260 \\
(22.7)\end{array}$ & & $\begin{array}{c}80 / 371 \\
(21.6)\end{array}$ & $\begin{array}{c}33 / 131 \\
(25.2)\end{array}$ & $\begin{array}{l}3 / 32 \\
(9.4)\end{array}$ & \\
\hline
\end{tabular}

"The data represents "correct answers (or the selections of the relevant options)/total answers", followed by the correct rates or the proportion (\%) in brackets. HBV, hepatitis B virus; PMTCT, prevention of mother-to-child transmission; HBIG, hepatitis B immunoglobulin; FPC, family planning centre. "Level 3 refers the highest level hospital in China. ${ }^{\S}$ Others include "occasionally" or "scarcely". 
the other $48.2 \%$ of physicians who did not recommend antiviral therapy.

It is recommended that infants born to $\mathrm{HBsAg}$ carrier mothers should be tested for HBsAg and antiHBs at age 9 to 18 months to determine whether the prophylaxis is successful [28]. Owing to the possible maternal blood contamination and transplacental leakage of maternal HBsAg and HBeAg to cord blood [32], detection of HBV serologic markers in cord blood or neonatal peripheral blood shortly after birth cannot determine whether the infants are infected [33]. However, only $38.2 \%$ of the respondents correctly answered this question in the present investigation. Indeed, such unreliable tests are performed in clinical practice [34], which may lead to waste of medical resources and excessive worries about infant infections if any of the cord blood HBV markers is ever positive.

When a pregnant woman's HBV status at delivery is unknown, a blood test is recommended as soon as possible, and her infant should receive HBIG and the first dose of vaccine within 12 hours of birth [28]. Although $71.9 \%$ of the respondents in the survey expressed that they would perform an emergency blood test, few hospitals can report the results in time, especially at night and holidays. Thus, in highendemic areas of HBV infection such as China, considering the high HBsAg carrier rates of pregnant women and the extremely high chronicity rates when infants are infected with HBV, newborns of pregnant women with unknown HBsAg status should receive HBIG even though it may cause some waste.

Noticeably, even if $95.3 \%$ of the respondents knew the necessity of giving of HBIG injection to infants of HBsAg positive mothers, fewer than $85 \%$ would "almost always" do so in daily practice, indicating that some medical staff do not strictly follow the proper preventive measures. Thus increased supervisory vigilance is warranted. Additionally, we found that the senior Obs/Gyn staff in tertiary hospitals unexpectedly had a lower correct rate in answering the questions on basic knowledge of HBV infection and prevention. This finding indicates that the relevant training should be strengthened not only in the junior staff but also in senior staff.

In this survey, the study subjects were mainly attendants who participated in national and local medical meetings. Since China has a vast, geographically diverse territory with unequal financial development, health providers in remote or isolated areas, as well as rural areas, seldom have opportunities to attend medical meetings. Therefore, the data of this survey reflects only the situations in Chinese cities and towns. Based on the insufficient knowledge in the Obs/Gyn staff in this survey, we can imagine that the scenario in rural and remote areas may be worse.

\section{Conclusion}

Obs/Gyn staff in China have basically mastered the prophylaxis strategies of HBV PMTCT, but there is obvious insufficiency in details of the application. Therefore, intensified efforts to train the Obs/Gyn staff are required to improve the currently suboptimal medical service provided to HBV-exposed infants and to control mother-to-infant transmission of HBV.

\section{Acknowledgements}

We are grateful to Dr. Biyun Xu for the statistical analysis. This study was funded by a Research Grant (2011271) for the National Key Department of Obstetrics and Gynecology from the Ministry of Health of China, and by a Special Research Grant (XK201102) for the Key Laboratory from the Department of Health, Jiangsu Province, China.

\section{References}

1. Chang MH (2007) Hepatitis B virus infection. Semin Fetal Neonatal Med 12: 160-167.

2. Ganem D and Prince AM (2004) Hepatitis B virus infection-natural history and clinical consequences. N Engl J Med 350: 1118-1129.

3. Liang X, Bi S, Yang W, Wang L, Cui G, Cui F, Zhang Y, Liu J, Gong X, Chen Y, Wang F, Zheng H, Wang F, Guo J. Jia Z, Ma J, Wang H, Luo H, Li L, Jin S, Hadler SC, Wang Y (2009) Epidemiological serosurvey of hepatitis B in China-declining HBV prevalence due to hepatitis $B$ vaccination. Vaccine 27: 6550-6557.

4. Zou L, Zhang W, Ruan S (2010) Modeling the transmission dynamics and control of hepatitis B virus in China. J Theor Biol 262: 330-338.

5. Zuckerman J, van Hattum J, Cafferkey M, Gjørup I, Hoel T, Rummukainen ML, Weiland O (2007) Should hepatitis B vaccination be introduced into childhood immunisation programmes in northern Europe? Lancet Infect Dis 7: 410419.

6. Libbus MK and Phillips LM (2009) Public health management of perinatal hepatitis B virus. Public Health Nurs 26: 353-361.

7. Andre FE and Zuckerman AJ (1994) Review: protective efficacy of hepatitis B vaccines in neonates. J Med Virol 44: 144-151.

8. Chen HL, Lin LH, Hu FC, Lee JT, Lin WT, Yang YJ, Huang FC, Wu SF, Chen SC, Wen WH, Chu CH, Ni YH, Hsu HY, Tsai PL, Chiang CL, Shyu MK, Lee PI, Chang FY, Chang MH (2012) Effects of maternal screening and universal immunization to prevent mother-to-infant transmission of HBV. Gastroenterology 142: 773-781.

9. Recommendations of the Immunization Practices Advisory Committee (1991) Hepatitis B virus: a comprehensive strategy for eliminating transmission in the United States through universal childhood vaccination. MMWR Recomm Rep 40: 1-25. 
10. Mahoney FJ (1999) Update on diagnosis, management, and prevention of hepatitis B virus infection. Clin Microbiol Rev 12: 351-366.

11. Chang MH, Chen CJ, Lai MS, Hsu HM, Wu TC, Kong MS, Liang DC, Shau WY, Chen DS (1997) Universal hepatitis B vaccination in Taiwan and the incidence of hepatocellular carcinoma in children. N Engl J Med 336: 1855-1859.

12. Zanetti AR, Van Damme P, Shouval D (2008) The global impact of vaccination against hepatitis B: a historical overview. Vaccine 26: 6266-6273.

13. Franco E, Bagnato B, Marino MG, Meleleo C, Serino L, Zaratti L (2012) Hepatitis B: Epidemiology and prevention in developing countries. World J Hepatol 4: 74-80.

14. Utsumi T, Yano Y, Lusida MI, Amin M, Soetjipto, Hotta H, Hayashi Y (2010) Serologic and molecular characteristics of hepatitis B virus among school children in East Java, Indonesia. Am J Trop Med Hyg 83: 189-193.

15. Centers for Disease Control and Prevention (2007) Progress in hepatitis B prevention through universal infant vaccination-China, 1997-2006. MMWR Morb Mortal Wkly Rep 56: 441445.

16. Luo Z, Li L, Ruan B (2012) Impact of the implementation of a vaccination strategy on hepatitis $B$ virus infections in China over a 20-year period. Int J Infect Dis 16: e82-88.

17. Chen WH, Yin CS, Chang YK, Yan JS, Chu ML (1998) Neonatal gastric aspirates as a predictor of perinatal hepatitis $\mathrm{B}$ virus infections. Int J Gynaecol Obstet 60: 15-21.

18. Pan CQ, Duan ZP, Bhamidimarri KR, Zou HB, Liang XF, Li J, Tong MJ (2012) An algorithm for risk assessment and intervention of mother to child transmission of hepatitis B virus. Clin Gastroenterol Hepatol 10: 452-459.

19. Op de Coul EL, Hahné S, van Weert YW, Oomen P, Smit C, van der Ploeg KP, Notermans DW, Boer K, van der Sande MA (2011) Antenatal screening for HIV, hepatitis B and syphilis in the Netherlands is effective. BMC Infect Dis 11: 185.

20. Hwang JP, Roundtree AK, Engebretson JC, Suarez-Almazor ME (2010) Medical care of hepatitis B among Asian American populations: perspectives from three provider groups. J Gen Intern Med 25: 220-227.

21. Lin HH, Kao JH, Hsu HY, Mizokami M, Hirano K, Chen DS (1996) Least microtransfusion from mother to fetus in elective cesarean delivery. Obstet Gynecol 87: 244-248.

22. Giles ML, Garland SM, Grover SR, Lewin SM, Hellard ME (2006) Impact of an education campaign on management in pregnancy of women infected with a blood-borne virus. Med J Aust 184: 389-392.

23. Wang J, Zhu Q, Zhang X (2002) Effect of delivery mode on maternal-infant transmission of hepatitis $B$ virus by immunoprophylaxis. Chin Med J (Engl) 115: 1510-1512.

24. Fiore S, Savasi V (2009) Treatment of viral hepatitis in pregnancy. Expert Opin Pharmacother 10: 2801-2809.
25. Yogeswaran K, Fung SK (2011) Chronic hepatitis B in pregnancy: unique challenges and opportunities. Korean $\mathrm{J}$ Hepatol 17: 1-8.

26. Zheng Y, Lu Y, Ye Q, Xia Y, Zhou Y, Yao Q, Wei S (2011) Should chronic hepatitis B mothers breastfeed? a meta analysis. BMC Public Health 11: 502.

27. Giles ML, Sasadeusz JJ, Garland SM, Grover SR, Hellard ME (2004) An audit of obstetricians' management of women potentially infected with blood-borne viruses. Med J Aust 180: 328-332.

28. Mast EE, Margolis HS, Fiore AE, Brink EW, Goldstein ST, Wang SA, Moyer LA, Bell BP, Alter MJ (2005) A comprehensive immunization strategy to eliminate transmission of hepatitis B virus infection in the United States: recommendations of the Advisory Committee on Immunization Practices (ACIP) part 1: immunization of infants, children, and adolescents. MMWR Recomm Rep 54: $1-31$

29. Giles ML, Visvanathan K, Lewin SR, Sasadeusz J (2012) Chronic hepatitis B infection and pregnancy. Obstet Gynecol Surv 67: 37-44.

30. Giles M, Visvanathan K, Sasadeusz J (2011) Antiviral therapy for hepatitis $\mathrm{B}$ infection during pregnancy and breastfeeding. Antivir Ther 16: 621-628.

31. Ahn J, Salem SB, Cohen SM (2010) Evaluation and management of hepatitis B in pregnancy: a survey of current practices. Gastroenterol Hepatol (NY) 6: 570-578.

32. Elefsiniotis IS, Papadakis $M$, Vlahos G, Daskalakis G, Saroglou G, Antsaklis A (2009) Clinical significance of hepatitis B surface antigen in cord blood of hepatitis B eantigen-negative chronic hepatitis B virus-infected mothers. Intervirology 52: 132-134.

33. Papaevangelou V, Paraskevis D, Anastassiadou V, Stratiki E, Machaira M, Pitsouli I, Haida C, Drakakis P, Stamouli K, Antsaklis A, Hatzakis A (2011) HBV viremia in newborns of $\mathrm{HBsAg}(+)$ predominantly Caucasian $\mathrm{HBeAg}(-)$ mothers. J Clin Virol 50: 249-252.

34. Hou GQ, Chen SS, Lee CP (2006) Pathogens in maternal blood and fetal cord blood using Q-PCR assay. Taiwan J Obstet Gynecol 45: 114-119.

\section{Corresponding author}

Huixia Yang

Department of Obstetrics and Gynecology

Peking University First Hospital

Peking University

Beijing, China

Telephone/Fax: +86-10-6651-3519

Email: huixiayang2012@126.com

Conflict of interests: No conflict of interests is declared. 